\title{
CHINESE FANS' PATRIOTISM CREATING QUANDARY IN THE DIGITAL MEDIA ERA
}

\section{Shiyu Zheng (a)}

(a) University of Warwick. Coventry, UK. Email: s.zheng.1[at]warwick.ac.uk

\begin{abstract}
China is considered to be a nation with the largest number of netizens and online fandom throughout the world. The power of netizens cannot be overlooked, particularly with regard to the digital mobilization of nationalism. In a recent event regarding a geographic map controversy spawned by the TV series of "Go Go Squid!" many netizens became fan patriots and activists for territorial integrity. This TV series caused tremendous resistance due to its showing an incomplete Map of China in one of its episodes on $31^{\text {st }}$ July 2019 . This research deploys three research methods of netnography (digital scraping of fan expression), a qualitative interview and commentary analysis to examine fans' engagement upon this sensitive issue in China. The fans of the series and its main character naturally divided into different groups to show their opposing standpoints. With the help of Chinese featured cyberspace, Chinese netizens were hierarchically grouped as either loyal fans of the series, general/ordinary fans of the actress, or fan patriots and fan activists of the nation. Ambivalent attitudes from state media intensified the debates to call for a much more robust mechanism to guide cyber fandom.
\end{abstract}

\section{Keywords}

Fan patriotism; Individual activism; Collective nationalism; Chinese cyberspace; Chinese TV series 


\title{
ПАТРИОТИЗМ КИТАЙСКИХ ФАНАТОВ СОЗДАЕТ ДИЛЕММУ В ЭПОХУ ЦИФРОВЫХ МЕДИА
}

\author{
Чжэн Шиюй (a) \\ (а) Университет Уорик. Ковентри, Великобритания. Email: s.zheng.1[at]warwick.ac.uk
}

\begin{abstract}
Аннотация
Китай считается страной с самым большим количеством нетизенов и онлайнфандомов. Нельзя упускать из виду мощь нетизенов, особенно при цифровой мобилизации национализма. Во время недавнего инцидента с картой в телесериале "Вперед, Кальмар!" большое количество нетизенов превратилось в фанпатриотов и активных борцов за территориальную целостность страны. Этот сериал вызвал огромное негодование в связи с демонстрацией неполной карты Китая в одном из эпизодов 31 июля 2019 года. В этой статье используются три метода нетнографии (анализ высказываний фанатов в сети), качественное интервью и анализ комментариев для изучения вовлечения фанатов в обсуждение в Китае этого деликатного вопроса. Фанаты сериала и его главной героини естественным образом разделились на разные группы, демонстрируя противоположные точки зрения. Китайские нетизены с помощью китайского киберпространства были иерархически сгруппированы как преданные поклонники сериала, обычные поклонники актрисы, фан-патриоты и фан-активисты нации, соответственно. Противоречивое отношение к этой ситуации со стороны государственных медиа подогрело дискуссии, призывающие к созданию механизма гораздо более надежного руководства кибер-фандомом.
\end{abstract}

\section{Ключевые слова}

Фан-патриотизм; индивидуальный активизм; коллективный национализм; Китайское киберпространство; Китайские сериалы

Это произведение доступно по лицензии Creative Commons «Attribution» («Атрибуция») 4.0 Всемирная 


\section{INTRODUCTION}

Every country has patriots. However, the ways patriotism is expressed differently across nations (Yang, 2019). In recent years, cyber patriotism is on the rise in China (Han, 2019). An increasing number of netizens choose to express personal or collective patriotic calls to digital peers. Some of them gradually evolve their identity as fans of the nation who love their country in the same way they love their idols. This is because nationalist dynamics upwell and spread to myriad news events such as the "South China Sea issue", the "Zhao Wei incident", the "Horton event", "THAAD dispute", etc. (Wu, Li, \& Wang, 2019). Because of these events, more and more fans who idolize the nation play a key role because of their love of the nation. Their supports or boycotts regarding nationalist dynamics have increased in frequency. They nicknamed China as the "Bro of A Zhong"1 to show their sibling-like love of China. This new kind of fan patriots have spawned diverse practices and as a result have become an increasingly controversial group in the studies of Chinese fandom because of their rapid growth and increased calls for cyber movements. They are growing a new community that has the power to express patriotic opinions online through both individual practices and organized collective events.

In order to better explore the deep reasons behind fans' patriotism as expressed in cyberspace, this article will connect Chinese nationalism and patriotism to the development of Chinese cyber culture and internet activism in the $21^{\text {st }}$ century via a case analysis of "Boycotting Yangzi". An analysis of fan patriotism requires elaboration upon differing degrees of fan identity in order to explain fan expressions in cyberspace. Since cyberspace can be regarded as a virtual community that reveals different emotions, ideas, and lifestyles, group behaviour in cyberspace needs to also be characterized by its underlying collective action (Liu, 2019). Within virtual communities, the role of individual fans and their diverse practices help to deconstruct fan patriotism in China. To this end, the author will analyse the individual and collective fan expressions to explain fan practices and the transfer of their ideas into culture at large. Given the background of the strengthened political and cultural censorship of cyberspace in modern China, this study attempts to incorporate fans' nationalistic practices within the current featured Chinese internet culture.

1 A Zhong is a Chinese interpretation of China. They have personated China as their brother to show the respect of their "idol"- China. 
Therefore, this article will explore how and why fan patriotism has been performed hierarchically and how individual fans became activists within the context of unique internet culture and fandom in Mainland China. This research draws on data collected through several different resources. First, the author conducted in-depth ethnographic research online by observing the targeted fan practices on Weibo ${ }^{1}$ pages and Zhihu forums. Second, based upon online observations, the author scraped the Top 20 popular posts with 25,536 comments on Weibo and Zhihu ${ }^{2}$ respectively (in a total of 40 posts) by hand to create the dataset for further analysis of fans' identities. Third, the author selected the top five news reports and commentaries containing the most online comments from representative state news agencies, such as People's Daily, in order to supplement data obtained through other means.

Based upon the collected data and analysis from the aforementioned methods, it is clear to see that fan patriotism in this article did not get authentic support from the state; instead, it employed various fan-related stakeholders in the market as directors, or agents of differing purposes and interests. The author utilizes the case of "Boycotting Yangzi" to observe fan types online such as the loyal fans who protected their idol (Yangzi) without succumbing to external influence from other parties, as well as ordinary fans who became fan patriots because of their love of the nation. The author also reviewed the above types of fans' practices and online performance in order to determine their reasons for engagement, and to discover why some ordinary fans became fan patriots. The classification of fan identities will be highlighted over the analysis of their practices, which involves degrees of loyalty, the mobilization of obsession, the extent of nationalism, and the rationale for their expressed form of patriotism (Han, 2019). Little scholarship has covered the phenomenon in China of an increasing number of fans becoming patriots due to sensitive political situations and the upsurge of fan nationalist movements. Hierarchical fan identities share different roles and responsibilities with regard to patriotism within the current cyberspace in China, according to the author's online observation. As a famous star, Yangzi shared the stigma of being mixed into groups of "fans" who flagged up their identity while carrying out efforts to boycott Yangzi and her fans (like an anti-fan). For this reason, the author proposes that a bipolar participatory fan culture is emerging through fan patriotism via "collective patriotism" and "individual activism” between loyal fans and ordinary (general) fans (Sandvoss

1 Weibo is a microblogging site in China, equivalent to Twitter.

2 Zhihu is a Chinese question-and-answer website where questions are created, answered, edited and organized by the community of its users 
\& Kearns, 2018). By the same token, it is not a negative signal to reveal that fan patriotism can be expressed under a disunified organization facilitated by technology. This means that these fans do not have a coherent connection and uniform organisation, but rather that they have worked out of self-interest and their own sense of patriotism, which technology both records and disseminates. Under this circumstance, Chinese featured cyber patriotism is dramatically distorted by fans and the resulting switch between collective patriotism and individual activism creates a bipolar fan culture - a new area of fandom studies in China.

\section{NATIONALISM AND PATRIOTIC EDUCATION}

There is no single definition of nationalism, even though nationalism is always considered to be a way to identify the concept of nations in general. Nationalism may include dimensions such as a sense of belonging, collective identity, and loyalty to a nation (He \& Guo, 2000). Defining what a nation actually is in contrast to nationalist views is key to understanding how nationalism arises within a nation's populace (Li, 2019). Previous scholars such as Benedict Anderson (1991) have made clear distinctions between nation and nationalism. Nation is a term used to define a group of people sharing the same language, origin, religion, and ancestry (Li, 2019). Anderson (1991) defines nation as "an imagined community and imagined as both inherently limited and sovereign" (p.3). Communitive practices such as media and mass communication support the construction of both the concept of nation and nationalism. Understanding nationalism and nation helped us understand the rise of nationalism $(\mathrm{Li}$, 2019).

Nationalism is a powerful and nearly universal sentiment that influences national and international politics in the modern world. The power of nationalism comes from the fact that it "locates the source of individual identity within a 'people', which is seen as the bearer of sovereignty, the central object of loyalty, and the basis of collective solidarity" (Greenfeld, 1992, p.3). China started to recognise the importance of national prosperity after the foundation of "New China" in 1949. The traumatic experience with other nations before 1949 produced a sense of inferiority in China and from then on, the recognition of nationalism came into the public mind (Pusey, 1983; Li, 2019). However, at that time, nationalism was characterized by vague concepts combined with an ambivalence derived from both a sense of victimization and an expression of patriotism ( $\mathrm{Li}, 2019)$. Since the foundation of the People's Republic of China (PRC) 1949, the Party in power - the Chinese Communist Party (CCP) - has officially and constantly constructed a sense of nationalism throughout the country. 
"Chinese nationalism seeks to orient its imagined community around a duality of narratives: 1) a negative thesis of resisting Western, imperialist humiliation, and 2) a positive thesis of national pride in the country's collective achievements, which are attributed to the collective sacrifices and hard work of the Chinese people." (Zhao, 2004; Wong, 2020). This duality has been applied on all sides of life as Chinese nationalism aims to build upon a strong sense of collectivism while simultaneously avoiding individualism among the populace. Collectivism became a key feature of Chinese nationalism. Especially in the post Deng-era, Chinese nationalism become increasingly bellicose, "adopting characteristics of what some term 'assertive' or 'aggressive' nationalism. The former refers to the country's continued efforts to establish its influence and status on the global stage; the latter denotes the country's militaristic and rhetorical escalation toward the West." (Wong, 2020, para.11). Due to the long history of being invaded, both the victim as well as victor narratives have been employed to counter imperialism. The Chinese government strengthened and reinforced such nationalistic tendencies via political and economic control, as well as through patriotic education led by the CCP following the foundation of the PRC (1949). "The concept of nationalism is often expressed in Chinese as aiguozhuyi (patriotism) (Zhao, 1998, p.290) while patriotism is considered to be a product of the nation-state system. "Chinese patriotism can be understood as a state-centric conception of nationalism or [...] a state-led nationalism". Under this circumstance, "schools, among other societal institutions, have been called upon to shape citizens' knowledge, attitudes, and behaviour toward society, the nation, and the state through political education (Fairbrother, 2004, p.157)".

Although the "content of patriotic education campaign was wideranging, three themes dominated the campaign: Chinese tradition and history, territorial integrity, and national unity" (Zhao, 2004, p.9). These three themes are linked closely with each other, so that the perception that Chinese tradition is under fierce attack has become the focus in patriotic education due to China's experience of a long history against foreign oppression and aggression (Zhao, 2004). Such tradition and history further amplify the significance of territorial integrity and national unity in the present day. The CCP reinforces this territorial integrity and national unity by means of national legislation, as well as designating a national map and national flag. In order to effectively implement this three-themed patriotic education, the CCP carried out its campaign through schools in order to maintain political stability and enforce intellectual stagnation (Fairbrother, 2004). Regular on-site meetings regarding patriotic education were held in primary and secondary schools; primary and secondary 
schools were required to watch patriotic movies recommended by the State Education Commission; the patriotic program and courses were introduced into the syllabus from primary to tertiary education, including but not limited to courses on Marxist political science. (Zhao, 1998). Forms of patriotism were not only limited to the education area, but were also expanded to the economic field. After the Cultural Revolution (19661976) and the Reform and Opening-up Policy (1978), the Chinese government relied on economic development to justify its legitimacy and the people's patriotism. China's economic reform greatly benefited the middle class, who were conservative and supported the patriotism constructed by $\mathrm{CCP}$ in general rather than seeking more freedom and democracy (Cheng \& Dickson, 2010). They accounted for the largest proportion of the Chinese population. This contrasted with the expectation from western politicians and had an apparent impact on people's cohesion and centripetal force. China's patriotism meanwhile called for more global participation in terms of economic and cultural exchange, which opened up the mindset to accept more information and media flows from the West. However, due to the major political movement ${ }^{1}$ in the early 1990s, "many elites shifted away from politics to business and money-making" (Li, 2019, p.17), which helped China to deepen its degree of global participation with regard to economics in order to develop increased consumerism. By contrast, the political movement also strengthened the control of information access in mainland China, which led to more oversight from the CCP and authorities of media presence and reports. From the 1990s to the 2000 s, the emergence of the internet dramatically changed people's access to information, products, and services. The internet played a key role in "producing and selling nationalism" (Li, 2019, p.22). Chinese people were able to receive more information from the West and their perception of patriotism was shaped daily, with the help of internet culture as well as the aforementioned state-led patriotic education (Song, Zhang, Qiao, Tang $\& \mathrm{Gu}, 1996)$. Therefore, the CCP has kept a close eye on the internet information dissemination.

\section{INTERNET CULTURE FOR CHINESE NATIONALISM}

In the mid-1990s, the internet culture began to mature. Cyber nationalism came into rise after 2000s. Consequently, more nationalism is now visible in cyberspace via online posts. Whereas the content of Chinese nationalism did not experience dramatic changes, novel internet information dissemination created a challenge to traditional expressions of nationalism and patriotism. Therefore, the CCP strengthened the control and gov-

1 Five Fourth Movement. 
ernance of internet information in order to target the netizens community. This strategy became a double-edged sword. Most Chinese netizens tended to show their support and respect for China, other than opposing views, due to the censorship and restriction of online expression. Chinese netizens were more careful in expressing their views on Chinese nationalism when inserting words to be recorded in the digital sphere(Yang, 2019), so that there were few differing opinions presented, even though the internet is considered to be a relatively free space of expression. Consequently, an increasing number of Chinese patriots followed the authoritative logic of economic development to extol the prosperity of China and emotionally argued against opposing voices who questioned modern prosperity as being compatible with patriotism. They demonstrate an increased sensitivity that makes them reactive toward patriotism because of the media censorship and the patriotism supported and enforced by the CCP. Over their reactive actions, "Boycotting Yangzi" is an example worthy of greater examination because it responded to the practitioners against territorial integrity and pro-Taiwan Independence reactively with its huge influence in Mainland China.

On $31^{\text {st }}$ July 2019, a patriotic campaign called “抵制杨紫 (in English Boycotting Yangzi" (actress and investor) in defence of the "One China Principle" took place in Chinese cyberspace. It was originated from an overwhelmingly heated Chinese TV series (Go Go Squid!) in July of 2019, produced by Yangzi, a popular actress and investor in China. In the broadcast of the episode (of the TV series) on $30^{\text {th }}$ July 2019, the Map of China was presented in an incomplete manner as it lost the key and sensitive parts of Taiwan, Southern part of Tibet, Hainan Island and Aksai Chin (China Youth Daily, 2019). On the next day, the state news agency, People's Daily (the official paper of China's state party) released a report to object to this televised depiction of the Map of China, which resulted in more debates on the internet. As the lead actress and producer of the series, Yangzi was immediately thrust into the limelight, denounced and blamed by fan patriots and those who had been watching the TV series. The incident was further aggravated when the director of the TV series was investigated and found to be a self-declared supporter of Taiwan independence. Following the aired episode, tens of thousands of critical comments and messages were left on Yangzi's personal Weibo account, and even many so-called Yangzi's fans criticised their idol out of patriotic sentiments. At the same time, another leading Chinese news media site, Zhihu, set up special Q\&A discussions for this incident, and more than 5,000 fans commented and answered the relevant questions within 24 
hours. Over the course of the event, the "loyal" fans of Yangzi came out to fight for their favourite star while the "ordinary (general)" fans insisted on their so-called justice to castigate Yangzi.

The incident took place because of well-established social and political conventions in China. The internet culture was initiated during the mid-1990s when Chinese society was experiencing a period of "unprecedented disenchantment" (Yang, 2019, p.1). Due to the transformation of the market economy and the emergence of commercial culture, Chinese society started to dramatically swing its moral orientation towards individualism, which became a distinct feature in the media-saturated politics of contemporary China (Yang, 2019). People were understood to be correct in their pursuit of personal interests and value, whereas previously collectivism had been viewed as the first priority over individualism since the foundation of People's Republic of China in 1949. This trend of individualism has become more prevalent in the internet culture over the first two decades of the $21^{\text {st }}$ century, especially due to the fact that Hong Kong and Taiwan are not directly governed by a Chinese central authority. In the second half of 2019, the rebellions of Hong Kong as well as Taiwan's independence being recognized by other countries have created an increased volatility. More events of cyber fan activism have taken place to resist the rebellions, creating huge waves of public opinions about the shape and strength of China's patriotism.

\section{CYBER FAN ACTIVISM}

The "Boycotting Yangzi" is a recent typical example of fan patriotism in China - it reflects the featured characteristic of fan activism in the civic engagement. Fans have been celebrated for their activism (Bennett, 2012; Jenkins \& Shresthova, 2012) whereas fan studies have not further developed with specific regard to Chinese fandom. The internet has played an important role in producing and constructing fan activism in the digital era. Through this process, fans have been divided into different subgroups via their diverse degrees of engagement and performance so that cyber fan categories are elaborated in detail with an emphasis on fan activism.

Over the past thirty years, "China has experienced the extremely rapid proliferation of information and communications technology (ICT) that has given rise to new social networks with unprecedented power" (Esarey \& Xiao, 2011, p. 298). Over these new social networks, fan activists created a unique network characterized by new forms of presence and expression in the digital era. As Pearson (2010, p. 87) argued, "it is fans' giving, receiving, and reciprocating which resulted in the creation of fan 
social networks". However, fans' giving, receiving, and reciprocating have been distorted in the discourse of online patriotism in China due to strong emotional, personal and extreme activism. China has witnessed a rapid proliferation of online fan activism and noteworthy presence in recent years due to the development of social media. For example, social media in China such as microblogs (Weibo) have "offered numerous channels and various platforms to participate in cultural practices in pursuit of all kinds of fan objects" (Zhang \& Mao, 2013, p. 45). The emergence of featured digital media sites such as Zhihu, Weibo, Post Bar, and others in China has boosted Chinese fans into the realm of activism despite the fact that most of them were general fans revealing no overt political aspirations in their daily communications. However, with regards to any emergent events, a certain group of fans became more vocal than any other member/peer group, a phenomenon ascribed to volunteerism and activism (Kligler-Vilenchik, McVeigh-Schultz, Weitbrecht \& Tokuhama, 2013). Therefore, the fan phenomenon of patriotic activism in China was born. In order to understand the rise of Chinese fandom as a form of patriotic activism, it is necessary to classify fan types first.

Generally, fans with high loyalty, social connection and textual productivity who engage themselves frequently in an object are categorised as active/loyal fans; the ones with general interests, passion and connection are considered to be general fans whereas those who lack "high levels of fan-based social connectivity and textual productivity" (Sandvoss \& Kearns, 2018, p. 93) are relegated to the group of ordinary fans. Fans have naturally divided themselves into different groups due to differing levels of patriotic engagement, with those who exhibit the strongest desire and high frequency of expression being considered as a new type of fan - the fan activist. This type of fan relies heavily upon the assistance of digital media to speed up the circulation of information that includes angry expressions, unleashing them beyond Chinese borders into the realm of cyberspace. They have become the Key Opinion Leaders (KOLs) in patriotic rhetoric, using their texts to condemn and denounce others. The pioneer fan scholar Henry Jenkins (2006) raised "fan activism out of the consumerist or cultural domain and laid out the ways in which fan activities start to change politics" (as cited in Zhang \& Mao, 2013, p. 48). Neta Kligler-Vilenchik, Joshua McVeigh-Schultz, Christine Weitbrecht, and Chris Tokuhama (2013, p.1) argued, "fan activism, forms of civic engagement and political participation growing out of experiences of fandom, is a powerful mode of mobilization, particularly for young people". Fan activism has been able to mobilize overt civic or political participation (Kligler-Vilenchik, McVeigh-Schultz, Weitbrecht \& Tokuhama, 2013, p.1). 
The culture of fan activism is now emerging as a networked practice combined with individualistic expression because their goal is to share more individual voices and personal interests in order to stand out against the background of collective goals. The author contends the individualism expressed within fan activism has become an important feature in Chinese cyberspace of fandom. The activists are also labelled as "Angry Youth" by some scholars (Osnos, 2008) in order to distinguish their activities from other types of fans. These fans would become extremely sad and angry "if their idols or objects of obsession fail to secure a leading role" (Wu, Li \& Wang, 2019, p.41-42). This trend is becoming increasingly predominant.

As Qiang (2011, p. 47) demonstrated, "China has the world's largest Internet market with over 400 million people online", while the "Chinese government has established the world's most extensive, sophisticated, and technologically advanced online censorship system". Under this censorship system, western social media sites such as Facebook and Twitter are forbidden in Mainland China. Although certain western social media sources have been blocked, the increasing influence of online public opinion from Chinese netizens shows that "the government can no longer maintain absolute control over the spread of information" (Qiang, 2011, p. 62). A survey conducted by the Chinese Academy of Social Sciences with regard to the Internet's impact on public opinion identifies netizens as a "new opinion class" that can swiftly influence society (Zhu, Shan \& $\mathrm{Hu}$, 2009). Consequently, fan activists have attained a noteworthy influence within the new opinion class which allows them to play a vital role in protecting their common idol - China. My observation indicates that fan activists have played a crucial role in leading Chinese fan patriotism among millions of netizens in China's cyberspace. Fan activists launched campaigns on the internet to call for action against loyal fans who protect the series and characters without any reasons. Fan activists organized thousands of posts with extreme and sensitive expression to assert the importance of national unity and territorial integrity that aims to overwhelm loyal fans of the series and Yangzi. Their protection of China served as a movement of patriotism that metamorphosed into fan activism in cyberspace that included a mix of points of view. Some of them were rational, well-behaved and logical while some were biased, onesided and brainless. Therefore, in order to target fan patriots and activists and their various self-expressions and performances for analyzing the case of "Boycotting Yangzi", the research methods are considered to be rigorous with regard to identifying the new Chinese fan types (fan patriots and activists), their expressions. The intention of this research is to 
provide a further understanding of how fan patriotism and its textual productivity becomes a means of political engagement and civic participation.

\section{RESEARCH METHODS}

As mentioned above, China has constructed its cyberspace with the largest number of netizens in the world while the rapid development of internet culture facilitated the growth of fan patriotism. Targeting appropriate fan-based digital platforms is difficult yet helpful in understanding fans' patriotic engagement and their self-expression. After the broadcast of the controversial episode of "Go Go Squid!", two prevalent digital platforms, Sina Weibo and Zhihu were overwhelmed by Chinese netizens who triggered heated discussions about the issue. Most of them rigorously criticized the incomplete Map of China in the public sphere while other fans disagreed in order to support their idol and favoured TV series.

The first method proposed to identify fans was online observation (netnography). The fan identity was deeply observed via the historical record of online posts and comments from the discussions and personal accounts on Sina Weibo and Zhihu. The author conducted in-depth netnographic research to define the specifics regarding fans and fan performance online. As Jenkins (1992) and Hills (2002) proposed, fans have been encyclopedic, knowledgeable, obsessed and enthusiastically devoted. They were experts on their object of interest, whereas how to identify a fan depended on productivity (Fiske, 1992). This situation revealed the principles needed to define fans related to the "Boycotting Yangzi" incident using two criteria - the frequency of online posts and mutual interaction towards the particular topic/discussion; combined with textual productivity including posts, updates and comments which can be partially traced by the above digital platforms.

The first research method led to the second research method - digital scraping designed to identify a specific category of Chinese fan. The key to recognizing a fan patriot arose from the online observation of fan posts because the fan patriots were digital natives, immersed in this incident and its related discussions and arguments. However, there were hundreds of comments followed by the posts. In order to accurately target fan patriots, the second research method relied upon both digital function and manual selection. To be more specific, Sina Weibo has launched the function in early 2019 to call out "loyal fans" by assessing the frequency of their posts and interactions with particular bloggers. Once an account owner had become a follower of an uploader/blogger for more than one month with over five days' interaction with the original uploader/blogger, 
he/she would be automatically labelled as a fan by Weibo. Other than the self-designed function on Weibo, the author also screened out the top 20 popular posts to analyze their content, form and followed discussions/ comments on each site manually. Zhihu's digital site is well-known nowadays for its large-scaled knowledge sharing and Q\&A platform in China. In contrast to Weibo, Zhihu does not have the function to clearly distinguish fan identity but does have the function to automatically list the answers with the most likes and recommendations by other fans of the same topic and certified as "professional". Thus, the author scraped the top 20 popular posts on each platform with the most comments and likes towards the discussion of "Boycotting Yangzi" and the incomplete Map of China in the series. By this method, the uploaders of these popular posts can be identified as a fan via their textual production, updates, likes and followers. Once the fans and their posts have been aimed at, the fan profiles, their historical post contents and following comments can all be targeted as research objects for further analysis.

In addition to online observation of Chinese fans' posts, and analysis of commentaries resulting from those posts, third parties' perspectives and their comments as the state media stakeholders were also analyzed. The author purposely screened out the top five news reports and commentaries with most clicks of reviews from the state news media platforms such as People's Daily and Xinhua Net, among others, to supplement the data obtained through other approaches. These pitched news reports/reviews contained different slants on official attitudes towards the incomplete Map of China and the "Boycotting Yangzi" controversy. All of them criticised the error of producing the Map of China with missing key parts, while at the same time commenting on the fan patriotism by denouncing Yangzi for differing reasons. The opposite perspectives from state news agencies were vital evidence used to gain deeper understanding of the contradictory attitudes from state media with regard to the rise of Chinese fan patriotism, which will be analyzed in detail below.

\section{FAN HIERARCHY AND PATRIOTISM}

The aforementioned research methods exploited different aspects of the incident. Self-expression of Chinese fans towards the incomplete Map of China was observed particularly from the online posts after the episode's broadcast. Different textual interpretations of the incident yielded diverse opinions about the incident. As Guobin Yang emphasises (2019, p.5) "style is a distinct feature in the media-saturated politics of the contemporary world." The varied methods of speaking, writing, acting, and displaying content online "merge into a symbolic whole that immediately 
fuses matter and manner, message and package, argument and ritual" (Pels, 2003, p.45). As acts of dramatic performance (Yang, 2009), Chinese fan patriotism reveals its own political expression. Styles of expression were diverse and depended upon fans' different degrees of loyalty towards the TV show and their sense of patriotism. Thus, "fan hierarchy" can be considered to be formed upon fans' degree of loyalty towards this series and Yangzi.

My own empirical research implies four layers of fan loyalty as demonstrated by fans' online posts and discussion. When the episode with the incomplete Map of China was broadcast on $31^{\text {st }}$ July 2019, a group of Chinese netizens noticed it immediately and posted their criticisms online, targeting both the map as well as the main character and investor of this series, Yangzi. Afterward, mainstream digital media sites such as Weibo and Zhihu were flooded by Chinese netizens discussing the obvious error in the Chinese Map displayed in the episode. Almost simultaneously, a small group of loyal fans of Yangzi and this series began their counterattack by arguing that any connection between the map problem and Yangzi was irrelevant. They made this assertion in order to protect their idol and her series no matter regardless of what had happened. These fans were also defined as brainless fans (in Chinese Pinyin: Naocan Fen) by Chinese netizens, which meant they irrationally supported their idol and her works (e.g. movies. TV series, etc.) regardless of any issues. The online dialogues of the so-called brainless fans are characterized by their insistence on the innocence of their idol, ignoring the fact of Yangzi as a main character and producer of the series. Being her most loyal fans, they were positioned at the first layer of hierarchy. Their defence of her immediately resulted in disgusting emotional diatribes from other fan members of Yangzi and the series.

The general fans, who accounted for the largest proportion of cyberspace fan peers, came onto the stage with a different voice to insist on the integrity of the territory of China while at the same time resisting Yangzi and her series. They were the second layer in the fan structure due to their moderate interest in the series, a small number of whom used their professional knowledge to correct the missing parts on the Map. One of the fan patriots certified by Zhihu as "professional" even wrote an article of approximately 3,000 words which included 14 pictures in order to prove the importance of the integrity of the map. The online post received more than 18,000 likes. However, observation of the professional voice online yielded evidence that this voice was unable to surpass the louder voices from a greater number of general fans who turned out to be fan patriots constituting the third layer of the fan hierarchy. They attributed 
the mistake of the map to Yangzi herself, denouncing her and her team collectively. These fan patriots worked together to criticize Yangzi for her investment in the series because she failed to demonstrate, through attention to the details of her series, the political value of patriotism. At the beginning, it was only a small team of fan patriots who posted arguable comments. As the discussion developed, a rapidly increasing number of fans started to condemn Yangzi and joined the category of anti-fan (Click, 2019) demonstrating hatred towards Yangzi and her loyal fans (brainless fans).

An examination of the historical online posts and interaction record revealed that fan patriots did not demonstrate as much fan-based social connectivity and textual productivity (Sandvoss \& Kearns, 2018) towards this series as loyal fans did, so that they were easy to turn their identity to become fan patriots in order to protect their declared patriotism. The result is that the higher degree of fan loyalty to the series and the star can be equated with a lower degree of fan patriotism. It seemed fan patriots sought to resonate with the official narratives of the profile of China (Han, 2019) and the state-led patriotic education to a deeper extent; so much so that a collective nationalism came into being through their collective voice and tremendous online presence.

General fans, seeing that their individuality was not being recognized, through their online behaviour showed they had transcended their status as ordinary fans, joining with fan activists who supported the nation. Consequently, they became the fourth layer of fan structure. Online active history and comments record showed they did not have a high degree of activity and enthusiasm for the topic discussions aimed at Yangzi - these fans were more silent and not as addicted to their idol as loyal fans were. Once the incident erupted online, they chose to support the nation other than their idol with slogans like "No idol is greater than our nation" or "Love your nation as you love an idol". By using these slogans, they exaggerated their anger and dissatisfaction via condemning Yangzi and launching the campaign of "Boycotting Yangzi". Individual interests spoke louder than collective goals (Zhang \& Mao, 2013) because they used and publicized aggressive expressions against loyal fans and their idol. Overwhelming messages and comments were left to the original posts from Yang's supporters (loyal fans) who sought to fight against different voices and thoughts in favour of Yangzi. As a result, fan activists have prevailed in terms of the number of posts and comments.

The author conducted the second research method (digital scrape) and collected the most liked 40 posts with 25,536 comments from Weibo and Zhihu up to $30^{\text {th }}$ August 2019. As high as $97.5 \%$ of posts opposed the 
airing of an incomplete Map of China in the episode, which is presented in Table 1. In order to further accurately target the fans' posts and their performance, the author screened out posts with more than 1,000 likes and 100 comments and marked them as the fan patriotism posts. Finally, a total of 18 posts were scraped with more than 12,378 comments.

\begin{tabular}{lll}
\multicolumn{3}{l}{ Posts from fans to positively/negatively boycott "Go Go Squid!" } \\
\hline Positive & Neutral & Negative \\
$97.5 \%(39 / 40)$ & $2.5 \%(1 / 40)$ & $0 \%$ \\
Example posts: & Example post: & N/A \\
"A good TV series is not & "It is difficult to determine \\
as important as & the reason of the mistake. \\
patriotism." & Anyway, it is a good series \\
& worth watching" & \\
"Do not watch 'Go Go & & \\
Squid' any more no & \\
matter how good it is." &
\end{tabular}

Fan patriotism posts to positively/negatively show fan identity of patriots (posts with more than 1,000 likes and 100 comments)

\begin{tabular}{lll}
\hline Positive & Neutral & Negative \\
$88.9 \%(16 / 18)$ & $11.1 \%(2 / 18)$ & $0 \%$ \\
Example posts: & Examples post: & N/A \\
"We are the protectors & "We do not want such plot/ \\
of our nation." & $\begin{array}{l}\text { scene to be broadcasted in } \\
\text { China" }\end{array}$ \\
$\begin{array}{l}\text { "Please get out of our } \\
\text { dearest motherland, the }\end{array}$ & \\
$\begin{array}{l}\text { director of the TV } \\
\text { series." }\end{array}$ &
\end{tabular}

Table1: Fans' attitudes towards Go Go Squid! and their patriotic identity

According to the answers to the question of "what is your view on the incomplete Map of China in the 'Go Go Squid!' series" on Zhihu, 88.9\% (16 posts) fans chose to become fan patriots and shared their sharp insights as individual patriots. They uploaded their posts to comment or evaluate the incident of displaying the incomplete Map of China and strongly resisted Yangzi and her series, including relevant stakeholders of the series. The group of fan patriots even investigated deeply and published online the personal background information of the director of "Go Go Squid?" who had professed to be a pro-Independence Taiwanese, which resulted in more fierce criticism online. 
Table 1 delineates online posts that display fans' anger. The high percentage of posts supporting a boycott was reiterated within the long-term patriotic education in China. Fan patriots viewed the Map of China as a carrier of Chinese patriotism while missing key parts of the map challenged the sensitive baseline of the fans of China. For instance, many fans flagged up their identity of patriots to boycott this series with the posts of "We are the protectors of our nation" or "We insist on the territorial integrity of our motherland". The director's background of pro-Taiwan Independence intensified fans' dissatisfaction and more fan patriots and activists emotionally urged authority and TV stations to stop broadcasting the TV series and refused to watch it. They adopted the slogan of "Roll out of our dearest motherland, the director of pro-Taiwan Independence".

In order to effectively resist the series invested by Yangzi, fans individually investigated the background of Yangzi's privacy such as her family, agent, company as well as her wealth and investment for this series. After the online campaign's explosion, the production team tried to seek explanations for the problematic Map of China in order to redeem themselves; however, their attempt at amelioration of the controversy only resulted in fan activists' refuting their explanations, point by point, based upon their own personal investigations. The fans ascended from the level of general/ordinary fans to fan patriots. Fan activists, step by step, mobilized their political participation while the controversy spread in cyberspace, which can be attributed to volunteerism and activism (KliglerVilenchik, McVeigh-Schultz, Weitbrecht, \& Tokuhama, 2012). As Henry Jenkins and Sangita Shresthova (2012, para. 1) defined, fan activism forms "civic engagement and political participation... in response to the shared interests of fans". In this case, fan activism fed back to participants' interests and patriotism, yielding a truth-telling via individual and active investigation that helped frame the participatory culture of fan activism. It revealed the online expression of anger and hatred as emotions characterizing "Angry Youth" (Osnos, 2008), through activism that prioritised patriotism in its efforts to make the public aware of the truth and details about Yangzi and the series. In this campaign, the group of fan patriots and activists spoke louder than the loyal fans who was defeated by a tremendous amount of comments and investigation.

In-depth online observations, including scraped 20 posts of each platform with more than 25,536 comments, provided one point of view on the subject. News reports and comments from state mainstream media revealed the point of view from state and official media outlets. The Ministry of Natural Resources of the People's Republic of China investigated the broadcast's serious political mistake, whereas other official news 
channels did not exactly concur with the Ministry's assessment of the incident. Xinhua Net (Xinhua Wang), The China Youth Daily (Zhongguo Qingnianbao), Communist Youth League (Zhongguo Gongqingtuan), and the mainland version of The People's Daily (Renmin Ribao) all criticized the error of broadcasting a fragmentary Map of China to the public, which gave rise to the misleading value of patriotism. However, the overseas version of People's Daily (Renmin Ribao Haiwaiban) encouraged Chinese people abroad to watch the TV series because it was of high production quality and positive energy. The series was reported to effectively promote China's younger generation's style of patriotism (which excluded the map) to the world.

The contradictory outlooks exhibited by the mainland and overseas versions of The People's Daily confused the public. Later, the mainland version of The People's Daily deleted critical comments about the problematic map in order to avoid contradiction and any instigation of greater expressions of anger by fan patriots. The changeable attitudes The People's Daily displayed toward the series revealed the complicated psychologies of state news media that created the dilemma of fan patriotism. On one hand, this TV series was supported and permitted to be broadcasted by China's State Administration of Press, Publication, Radio, Film and Television (hereafter "SAPPRFT"). The official authority had promoted the series because of its high rate of viewership after its broadcast. Despite the egregious error of the Map, the criticism from official news seemed inappropriate in face of the official approval from SAPPRFT of the series and its documented overwhelming viewership. On the other hand, the series did in fact commit a political and nationalistic error when it displayed the incomplete Map of China. This error led to large scale fan patriotism evidenced by both expressions of collective patriotism and individual activism. Without proper support from official news agencies, there is no doubt that fan patriotism would have found itself in a predicament. After all, The People' Daily is one of the most authoritative state news media in China for delivering official voices representing the party-state. Their ambivalent stance in this instance resulted in misleading public opinion.

The fluctuation of news releases from support and encouragement to criticism, and then to deletions further complicated the contradictory attitudes of authoritative parties toward fan patriotism and official nationalism represented by the series. As found through the observation of fans' posts on Zhihu, The People's Daily called for rational voices from the fans, because it did not want to present standpoints in support of fans' patriotism since they might easily lead to activism such as blame and ab- 
use. However, in face of the important political error of the Map of China in the series, official news cannot ignore the factual mistakes; rather, these entities need to conform to the official state's formal approval. The strong reaction from fan patriots forced official news to turn down their voice to avoid any large and provocative political movement. Fan patriotism thus has been put into a predicament within the featured political and media environment in China. The collective boycott of Yangzi and this series declined quickly after the deletion of official news presence, with a tiny proportion of fan activists left to denounce Yang.

\section{CONCLUSION}

Based on an in-depth online observation of the targeted fan posts on Weibo pages and Zhihu forum discussions, the digital scrape of 40 posts with a detailed emphasis of 18 popular posts, and the analysis of news comments/reviews from state news agencies/media, the article draws the conclusion that cyberspace in China has enabled more powerful fan engagement, individual empowerment and political participation. Chinese cyberspace has dramatically facilitated and stimulated fans' collective action and expression towards a sensitive political incident. As Rongbin Han (2019, p.355) argues, cyber nationalism "is clearly a form of individual empowerment for many citizens, allowing them to act on behalf of a grand goal." China has a long term of patriotic education so that the territorial integrity and sovereignty has been viewed as a key signal of patriotism. A national flag and a national map (in the case of "Boycotting Yangzi") were regarded as the representative of the nation as well as the carrier of patriotism. China has established a robust patriotic education system to shape people's mindset of patriotism since 1949. The author therefore redefined the campaign of "Boycotting Yangzi" as a form of fan patriotism as it resonated with the state-led patriotic education, official narratives of territorial integrity with strong affective affinities and social connection (Chin \& Morimoto, 2013). The analysis of "Boycotting Yangzi" presented a high degree of collective nationalism and mobilization of fan patriotism.

In response to the presence of the incomplete Map of China in the popular TV series of "Go Go Squid?", fans initiated the campaign of "Boycotting Yangzi". It is reactive in the sense that it took place "in response to external threats or the stigmatization of China" (Yang, 2019, p. 9). The participants were major fans of the series and its main character of Yangzi while a majority of them turned out to be fan patriots after the map issue. However, not all fans smoothly managed the identity change over the process. The author conducted online observation of fans' historical posts 
and interaction records to determine the common feature of those fans who chose to transfer their identity from being fans of Yangzi and the series to being fans of China. They were ordinary/general fans without high loyalty and connection with their idol or star. In the face of emergency events that stigmatized China, the group of general and ordinary fans easily transferred their identity via collective voices and individual engagement.

In the campaign of "Boycotting Yangzi", loyal fans of the TV show were termed as brainless fans who protected their idol regardless of any issues, which led to the aggressive counterattack from the fan patriots. This new mobilisation of fan patriotism gradually evolved into individual activism as more ordinary fans attempted to express their suppressed voices as individuals. Some fan activists sneaked into the group of fan patriots to attack Yangzi and her team with unfriendly expressions while other fan patriots attempted to appeal to patriotism. The online expression of fan patriotism was disorganised and disunited, which in and of itself is not a negative indication of cynical cyber-patriotism expressed by fans under a disunified organization by technological means. Under this circumstance, Chinese featured cyber patriotism has been reconstructed by fans of China based upon rooted patriotic education, which highlighted the importance of paying extra attention to the special groups of fans of China.

The different parties of fans argued for opposite standpoints towards patriotism. Therefore, the author contends that a bipolar patriotic fan culture is emerging in the context of Chinese fan patriotism via "collective patriotism" and "individual activism" between loyal fans and ordinary/ general fans. It has become a trend to simply transfer fan identities and associated attitudes when encountering sensitive events that affect Chinese patriotism. The bipolar fan culture grows into a new phenomenon in current Chinese cyberspace due to the rapid development of fan patriotism and the prominence of Chinese internet culture. In the digital era, bipolar fan patriotism culture must be reviewed critically from the lens of individual activism and collective patriotism in the face of digital political movement. The author suggests a more robust official mechanism to tackle these emergent events regarding nationalism/patriotism in order to avoid the ambivalence and grey zone resulting from misleading value statements about patriotism exhibited in the bipolar fan culture. The official accounts of Chinese authorities could be introduced to lead the voice of the campaign while more civic fan groups/communities are suggested to be organized to call for rational and reasonable actions in the 
digital sphere. For dealing with Chinese fans' bipolar engagement towards sensitive political and patriotic campaign in the digital media era, the issue needs further exploration in future studies.

\section{ACKNOWLEDGMENT}

This research received no specific grant from any funding agency in the public, commercial, or not-for-profit sectors.

\section{References}

Anderson, B. (1991). Imagined communities: Reflections on the origin and spread of nationalism. London: Verso.

Bennett, L. (2012). Fan activism for social mobilization: A critical review of the literature. Transformative Works and Cultures, (10), 15. Doi: 10.3983/twc.2012.0346.

Chin, B., \& Morimoto, L. (2013). Towards a theory of transcultural fandom. Participations: Fournal of Audience and Reception Studies, 10(1), 92-108.

China Youth Daily. (2019). More than one problem on the map of China in the Go Go Squid!. Retrieved from https://news.sina.com.cn/c/2019-08-02/docihytcerm7 970 022.shtml

Chinese nationalism used to be aimed at both domestic and foreign audiences. Not anymore (26 May 2020). The Diplomat. Retrieved from https://thediplomat.com/ 2020/05/how-chinese-nationalism-is-changing/

Click, M. (Ed.). (2019). Anti-Fandom: Dislike and Hate in the Digital Age. NYU Press.

CNNIC (Chinese Network Internet Information Centre) (2019, September). Survey Report of the Chinese Internet. Retrieved from: http:// www.cnnic.net/hlwfzyj/hlwxzbg/ hlwtjbg/201 608/P0 20160803367337470 363.pdf

Coenders, M., Gijsberts, M. \& Scheepers, P. (2017). Chauvinism and patriotism in 22 countries. In Nationalism and exclusion of migrants (pp. 29-69). Routledge.

Duara, P. (1993, July). De- constructing the Chinese nation. The Australian fournal of Chinese Affairs, (30), 1-26. Doi: 10.2307/2 949990

Esarey, A., \& Xiao, Q. (2011). Digital communication and political change in China. International fournal of Communication, 5, 22.

Fairbrother, G. P. (2004). Patriotic education in a Chinese middle school. In Citizenship education in Asia and the pacific (pp. 157-174). Springer, Dordrecht.

Fiske, J. (1992). The cultural economy of fandom. In Lisa A. Lewis (Ed.) The adoring audience: Fan culture and popular media (pp. 30-49). Psychology Press.

Greenfeld, L. (1992). Nationalism: five roads to modernity. Harvard University Press, Cambridge, MA. 
Hailong, L. (Ed.). (2019). From cyber-nationalism to fandom nationalism: The case of Diba expedition in China. Routledge.

Han, R. (2019). Patriotism without state blessing: Chinese cyber nationalists in a predicament. In Handbook of Protest and Resistance in China. Edward Elgar Publishing.

Hills, M. (2003). Fan cultures. London: Routledge.

Jenkins, H. (1992). Textual poachers: Television fans and participatory culture. Routledge.

Jenkins, H., \& Shresthova, S. (2012). Up, up, and away! The power and potential of fan activism. Transformative Works and Cultures, (10), 1-5. Doi: 10.3983/ twc.2012.0435.

Kligler-Vilenchik, N., McVeigh-Schultz, J., Weitbrecht, C., \& Tokuhama, C. (2012). Experiencing fan activism: Understanding the power of fan activist organizations through members' narratives. Transformative Works and Cultures, 10. Doi: 10.3983/twc.2012.0322.

Li, H. (2019). Understanding Chinese nationalism. In Hailong, L. (Ed.), From Cyber-nationalism to Fandom Nationalism: The Case of Diba Expedition in China (pp. 1331). London: Routledge.

Liu, (2019). Collective action as interaction ritual in cyberspace. Hailong, L. ed., 2019. From Cyber-nationalism to Fandom Nationalism: The Case of Diba Expedition in China. pp. 93-108. London: Routledge.

Osnos, E. (2008, July 8). Angry youth: The new generation's neocon nationalists. $8^{\text {th }}$ July, 2008. The New Yorker.

Pels, D. (2003). Aesthetic representation and political style: Re- balancing identity and difference in media democracy. In J. Corner \& D. Pels (Eds.), Media and the restyling of politics: Consumerism, celebrity and cynicism (pp. 41- 66). London: Sage.

Qiang, X. (2011). Liberation Technology: The Battle for the Chinese Internet. fournal of Democracy, 22(2), 47-61. Doi: 10.1353/jod.2011.0020

Sandvoss, C. \& Kearns, L. (2018). From interpretive communities to interpretative fairs: ordinary fandom, textual selection and digital media. In Reijnders, S., Zwaan, K. and Duits, L. (Eds.), The Ashgate research companion to fan cultures (pp.91108). Farnham: Ashgate Publishing, Ltd.

Song, Q, Zhang, C., Qiao, B., Tang, Z. \& Gu, Q. (1996). China Can Say No. (中国可以说 不.) Beijing, China: Zhongguo Gongshanglian Chubanshe. (In Chinese)

Wong, B. (2020). How Chinese Nationalism Is Changing. Retrieved from https://thediplomat.com/2020/05/how-chinese-nationalism-is-changing/

Wu, J., Li, S., \& Wang, H. (2019). From Fans to "Little Pink": The production and mobilization mechanism of national identity under new media commercial culture. In Hailong, L. (Ed.)? From Cyber-nationalism to Fandom Nationalism: The Case of Diba Expedition in China (pp. 32-52). London: Routledge. 
Yang, G. (2009). The power of the internet in China: Citizen activism online. New York, NY: Columbia University Press.

Yang, G. (2019). Performing cyber-nationalism in twenty-first-century China: The case of Diba Expedition. In From Cyber-Nationalism to Fandom Nationalism (pp. 112). Routledge.

Zhang, W., \& Mao, C. (2013). Fan activism sustained and challenged: participatory culture in Chinese online translation communities. Chinese fournal of Communication, 6(1), 45-61. Doi: 10.1080/17544750.2013.753499.

Zhao, S. (1998). A state-led nationalism: The patriotic education campaign in postTiananmen China. Communist and Post-Communist Studies, 31(3), 287-302. Doi:

Zhao, S. (2004). A nation-state by construction: Dynamics of modern Chinese nationalism. Stanford University Press.

Zhu, H., Shan X., \& Hu., J. (2009). "2009 China Internet Public Opinion Analysis Report," in Chinese Academy of Social Sciences, "2010 Society Blue Paper," 22 December 2009.

\section{Список литературы}

Anderson, B. (1991). Imagined communities: Reflections on the origin and spread of nationalism. London: Verso.

Bennett, L. (2012). Fan activism for social mobilization: A critical review of the literature. Transformative Works and Cultures, (10), 15. Doi: 10.3983/twc.2012.0346.

Chin, B., \& Morimoto, L. (2013). Towards a theory of transcultural fandom. Participations: Journal of Audience and Reception Studies, 10(1), 92-108.

China Youth Daily. (2019). More than one problem on the map of China in the Go Go Squid!. Retrieved from https://news.sina.com.cn/c/2019-08-02/docihytcerm7 970 022.shtml

Chinese nationalism used to be aimed at both domestic and foreign audiences. Not anymore (26 May 2020). The Diplomat. Retrieved from https:/thediplomat.com/ 2020/05/how-chinese-nationalism-is-changing/

Click, M. (Ed.). (2019). Anti-Fandom: Dislike and Hate in the Digital Age. NYU Press.

CNNIC (Chinese Network Internet Information Centre) (2019, September). Survey Report of the Chinese Internet. Retrieved from: http:// www.cnnic.net/hlwfzyj/hlwxzbg/ hlwtjbg/201 608/P0 $20160803367337470363 . p d f$

Coenders, M., Gijsberts, M. \& Scheepers, P. (2017). Chauvinism and patriotism in 22 countries. In Nationalism and exclusion of migrants (pp. 29-69). Routledge.

Duara, P. (1993, July). De- constructing the Chinese nation. The Australian fournal of Chinese Affairs, (30), 1-26. Doi: 10.2307/2 949990

Esarey, A., \& Xiao, Q. (2011). Digital communication and political change in China. International fournal of Communication, 5, 22. 
Fairbrother, G. P. (2004). Patriotic education in a Chinese middle school. In Citizenship education in Asia and the pacific (pp. 157-174). Springer, Dordrecht.

Fiske, J. (1992). The cultural economy of fandom. In Lisa A. Lewis (Ed.) The adoring audience: Fan culture and popular media (pp. 30-49). Psychology Press.

Greenfeld, L. (1992). Nationalism: five roads to modernity. Harvard University Press, Cambridge, MA.

Hailong, L. (Ed.). (2019). From cyber-nationalism to fandom nationalism: The case of Diba expedition in China. Routledge.

Han, R. (2019). Patriotism without state blessing: Chinese cyber nationalists in a predicament. In Handbook of Protest and Resistance in China. Edward Elgar Publishing.

Hills, M. (2003). Fan cultures. London: Routledge.

Jenkins, H. (1992). Textual poachers: Television fans and participatory culture. Routledge.

Jenkins, H., \& Shresthova, S. (2012). Up, up, and away! The power and potential of fan activism. Transformative Works and Cultures, (10), 1-5. Doi: 10.3983/ twc.2012.0435.

Kligler-Vilenchik, N., McVeigh-Schultz, J., Weitbrecht, C., \& Tokuhama, C. (2012). Experiencing fan activism: Understanding the power of fan activist organizations through members' narratives. Transformative Works and Cultures, 10. Doi: 10.3983/twc.2012.0322.

Li, H. (2019). Understanding Chinese nationalism. In Hailong, L. (Ed.), From Cyber-nationalism to Fandom Nationalism: The Case of Diba Expedition in China (pp. 1331). London: Routledge.

Liu, (2019). Collective action as interaction ritual in cyberspace. Hailong, L. ed., 2019. From Cyber-nationalism to Fandom Nationalism: The Case of Diba Expedition in China. pp. 93-108. London: Routledge.

Osnos, E. (2008, July 8). Angry youth: The new generation's neocon nationalists. $8^{\text {th }}$ July, 2008. The New Yorker.

Pels, D. (2003). Aesthetic representation and political style: Re- balancing identity and difference in media democracy. In J. Corner \& D. Pels (Eds.), Media and the restyling of politics: Consumerism, celebrity and cynicism (pp. 41- 66). London: Sage.

Qiang, X. (2011). Liberation Technology: The Battle for the Chinese Internet. Fournal of Democracy, 22(2), 47-61. Doi: 10.1353/jod.2011.0020

Sandvoss, C. \& Kearns, L. (2018). From interpretive communities to interpretative fairs: ordinary fandom, textual selection and digital media. In Reijnders, S., Zwaan, K. and Duits, L. (Eds.), The Ashgate research companion to fan cultures (pp.91108). Farnham: Ashgate Publishing, Ltd. 
Song, Q, Zhang, C., Qiao, B., Tang, Z. \& Gu, Q. (1996). China Can Say No. (中国可以说 不.) Beijing, China: Zhongguo Gongshanglian Chubanshe. (In Chinese)

Wong, B. (2020). How Chinese Nationalism Is Changing. Retrieved from https://thediplomat.com/2020/05/how-chinese-nationalism-is-changing/

Wu, J., Li, S., \& Wang, H. (2019). From Fans to "Little Pink": The production and mobilization mechanism of national identity under new media commercial culture. In Hailong, L. (Ed.)? From Cyber-nationalism to Fandom Nationalism: The Case of Diba Expedition in China (pp. 32-52). London: Routledge.

Yang, G. (2009). The power of the internet in China: Citizen activism online. New York, NY: Columbia University Press.

Yang, G. (2019). Performing cyber-nationalism in twenty-first-century China: The case of Diba Expedition. In From Cyber-Nationalism to Fandom Nationalism (pp. 112). Routledge.

Zhang, W., \& Mao, C. (2013). Fan activism sustained and challenged: participatory culture in Chinese online translation communities. Chinese fournal of Communication, 6(1), 45-61. Doi: 10.1080/17544750.2013.753499.

Zhao, S. (1998). A state-led nationalism: The patriotic education campaign in postTiananmen China. Communist and Post-Communist Studies, 31(3), 287-302. Doi: 10.1016/S0967-067X(98)00 009-9

Zhao, S. (2004). A nation-state by construction: Dynamics of modern Chinese nationalism. Stanford University Press.

Zhu, H., Shan X., \& Hu., J. (2009). "2009 China Internet Public Opinion Analysis Report," in Chinese Academy of Social Sciences, "2010 Society Blue Paper," 22 December 2009. 